\title{
Effective Uses of NOx and Drainage are Clever Way to Protect Global Warming and to Increase Fish Production
}

\author{
Shoichiro Ozaki* \\ The Institute of Physical and Chemical Research, Japan
}

Submission: August 05, 2017; Published: August 28, 2017

*Corresponding author: Shoichiro Ozaki, The Institute of Physical and Chemical Research, 2-1 Hirosawa, Wakoshi Saitama, Japan, Tel: +81-0467670991; Email: ozaki-0991@jcom.zaq.ne.jp

\begin{abstract}
The earth is warmed up by the burning of fossil releasing $\mathrm{CO}_{2}$. If we can compensate the generation of $\mathrm{CO}_{2}$ by $\mathrm{CO}_{2}$ assimilation, global warming can is protected. To promote $\mathrm{CO}_{2}$ assimilation, supply of nutrient $\mathrm{N}$ and $\mathrm{P}$ is essential. NOx is produced when fossil is burned. NOx is critically important for plant growth. Japan government ask us to eliminated NOx in burned gas and ask us to eliminate N, P in drainage. Fish production decreased $70 \%$ in past 30 years. When we look at fish industry of many country, the country which use NOx in burned gas and N, $\mathrm{P}$ in the drainage are producing much fish and fixing much $\mathrm{CO}_{2}$ and contributing for the protection of global warming. Effective uses of $\mathrm{NOx}$ and drainage are clever way to protect global warming and to get many fish.
\end{abstract}

assimilation

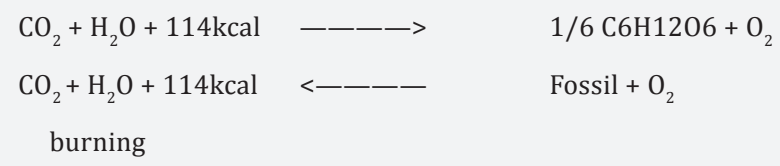

NOx is a main nutrient nitrogen sources. Plants are growing by eating $\mathrm{CO}_{2}$, water and nutrient. N.P. Plant cannot grow without nutrient N.P.

Nature look likes to set up system to make NOx to promote $\mathrm{CO}_{2}$ assimilation to promote plant growth. Nature also look like to make thunder [39-41] to make NOx, by following reaction.

$\mathrm{N}_{2}+\mathrm{O}_{2} \longrightarrow \longrightarrow \longrightarrow 2 \mathrm{NO}-43.2 \mathrm{kcal}$

Keywords: NOx; Carbon dioxide; Carbon dioxide assimilation; Global warming; NOx elimination; Fish

\section{Introduction}

The earth is warmed up by the heat and $\mathrm{CO}_{2}$ evolved by the burning of fossil, Most (probably 95\%) $\mathrm{CO}_{2}$ evolved is fixed by plant by $\mathrm{CO}_{2}$ assimilation. But burning of fossil is so much. $\mathrm{CO} 2$ assimilation cannot follow.

If we can compensate the generation of $\mathrm{CO}_{2}$ and heart of burning with the absorption of $\mathrm{CO}_{2}$ and heart by $\mathrm{CO}_{2}$ assimilation, global warming will be protected (1-11). NOx is produced when fossil is burned. NOx is essential compound for plant growth. Many governments hating NOx as pollution gas and set laws to elimination NOx. I wish to insist that NOx elimination should be stopped to increase $\mathrm{CO}_{2}$ assimilation and protect global warming.
To promote $\mathrm{CO}_{2}$ assimilation, the supply of nutrient nitrogen and phosphorous is essential. Many $\mathrm{CO}_{2}$ assimilation studies (12-38) indicated that $\mathrm{CO}_{2}$ assimilation is playing very important role for the regulation of climate and supply of nutrient N.P is important for the promotion of $\mathrm{CO}$ assimilation.

NOx is a main nutrient nitrogen sources. Plants are growing by eating $\mathrm{CO}_{2}$, water and nutrient N.P. Plant cannot grow without nutrient N.P. NOx is main promotor of $\mathrm{CO}_{2}$ assimilation and promotor of protection of global warming.

Nature look likes to set up system to make NOx to promote $\mathrm{CO}_{2}$ assimilation to promote plant growth. Nature also looks like to make thunder (39-41) to make NOx, 


\section{Stop NOx Elimination to Promote $\mathrm{CO}_{2}$ Assimilation and to Increase Fish Production}

NOx is hated as pollution gas. Many governments set up very strict laws to eliminate NOx in burned gas and forced to eliminate all NOx using ammonia. To kill one fertilizer with other fertilizer gives tremendous loss for the growth of plant. Nutrient nitrogen and phosphorous in drainage is also hated as pollution elements and many governments set up very strict laws to eliminate all nutrient nitrogen and phosphorus and forced to eliminate these elements using much electricity.

I was born in 1930 at small town Kojima, Kurashiki, Japan. This town is located at sea beach in Setoinland sea, Japan. The bottom of the sea was filled with sea weed. This is clear from my swimming experience at swimming shore. There is swimming beach at small village, named Hikiami beach seine). When swimming at tide is down, leg touched sea weed and stone fish. Sea shore was filled with dried sea weed especially that cast ashore. The sea was filled with plankton and fish, Bream (tai), Eel (unagi), Sea eel (anago), Octopas, Sardin (iwashi), Shrimps, Ikanago. The sea was filled with fishing boat. Fish was very low price than meat. Main protein source of Japanese was fish before 1945. The ratio fish/meat was $100 / 1$

Table 1:

\begin{tabular}{|c|c|c|c|c|c|}
\hline \multicolumn{4}{|c|}{ Fish Production Million Tone } & \multirow{2}{*}{$\begin{array}{c}\text { Population } \\
\text { Billion }\end{array}$} & \multirow{2}{*}{$\begin{array}{c}\mathrm{CO}_{2} \\
\text { Fixed By } \\
\text { Plankton } \\
\text { Million } \\
\text { Tone }\end{array}$} \\
\hline & & 2016 & 1997 & & \\
\hline Top & China & 79.38 & 16.29 & 13.5 & 794 \\
\hline 2nd & Indonesia & 22.21 & 5.55 & 2.39 & 222 \\
\hline 3 & India & 10.11 & 3.6 & 12.24 & 101 \\
\hline 4 & Vietnam & 6.21 & & 0.86 & 62 \\
\hline 5 & USA & 6.05 & 5.41 & 3.1 & 60 \\
\hline 6 & Peru & 4.92 & 7.87 & 0.28 & 49 \\
\hline 7 & Japan & 4.64 & 5.88 & 1.27 & 46 \\
\hline 8 & Russia & 4.61 & 4.66 & 1.43 & 46 \\
\hline 9 & Philippine & 4.5 & & 0.92 & 45 \\
\hline 10 & Norway & 3.52 & 2.87 & 0.48 & 35 \\
\hline 11 & Bangladesh & 3.68 & & 1.48 & 37 \\
\hline 12 & Korea & 3.33 & & 0.4 & 33 \\
\hline 13 & Chile & 3.19 & 5.87 & 0.17 & 32 \\
\hline 14 & Myanmar & 2.95 & & 0.48 & 30 \\
\hline 15 & Tai & 2.59 & & 0.63 & 26 \\
\hline 16 & Malaysia & 2 & & 0.28 & 20 \\
\hline
\end{tabular}

But since NOx, nutrient $\mathrm{N}, \mathrm{P}$ elimination policy and elimination law were established at around 1980. Concentration of $\mathrm{N}, \mathrm{P}$ of sea water decreased. Concentration of nitrogen in rain dropped to zero. No weed, no plankton grow at Setoinland sea. Hundred thousand fisherman lost job. Most fish shops were closed. We cannot buy fish produced at Setoinland sea. At Setoinland sea, 500 thousand tone fish was produced in 1980. But it decreased to 50 thousand tone now. This indicates that $\mathrm{CO}_{2}$ assimilation by plankton was lost by the NOx and nutrient $\mathrm{N}, \mathrm{P}$ elimination policy. Fish production of Japan 16 million tone in 1980 was top in the world, but it decreased to 4.64 million tone 7th place in 2015 (Table 1).

Japan is eliminating 3 million tone $\mathrm{N}$ and $\mathrm{P}$. Therefore 16 million tone fish was not produced in recent years. China, Indonesia, India, Vietnam do not eliminate NOx and do not do drainage treatment They use NOx and excreta as it is for production of plankton and fish. Therefore, fish production increased remarkably in the district where no N, P supply by counter current of nutrient rich deep sea water with nutrient poor shallow sea water.

Fish production is proportional to population, amount of excreta. Shrimp production by excreta is popular in Vietnam, India and Indonesia and 31000, 30000 and 25000 tone shrimps are exported to Japan respectively in 2015. Peru, Norway and Chile produce much fish by $\mathrm{N}, \mathrm{P}$ caused by counter current of nutrient rich deep sea water with nutrient poor shallow sea water.

Fish production is proportional to $\mathrm{CO}_{2}$ fixed by $\mathrm{CO}_{2}$ assimilation at sea, The country having high fish production is the country which have done high $\mathrm{CO}_{2}$ fixing. 10 times of $\mathrm{CO}_{2}$ of fish production are fixed by plankton $\mathrm{CO}_{2}$ assimilation. China produced 79.38 million tone fish in 2016. This means that China fixed 8 billion tone. $\mathrm{CO}_{2}$ by plankton $\mathrm{CO}_{2}$ assimilation. This is huge amount. This is $1 / 12$ of 100 billion tone $\mathrm{CO}_{2}$ produced at China. China is biggest $\mathrm{CO}_{2}$ producing country.

This data indicates that plankton $\mathrm{CO}_{2}$ assimilation is playing significant role for the fixing of $\mathrm{CO}_{2}$ and protection of global warming. Decrease of 12 million tone fish at Japan means decrease of 120 million tone $\mathrm{CO} 2$ fixing. If Japan stop elimination of 3 million tone $\mathrm{N}$ and $\mathrm{P}$, Japan can fix 46 million tone $\mathrm{CO}_{2}$ and can produce 12 million tone fish. Decrease of half million tone fish at Setoinland sea means decrease of 5 million tone $\mathrm{CO}_{2}$ fixing.

Japan is most $\mathrm{CO}_{2}$ increasing country, because country is narrow and cannot fix produced $\mathrm{CO}_{2}$ at land [11]. Therefore Japan must fix $\mathrm{CO}_{2}$ by promotion of $\mathrm{CO}_{2}$ assimilation at sea. Japan is producing $10 \% \mathrm{CO}_{2}$ of total $\mathrm{CO}_{2}$ production for the elimination of NOx and drainage treatment. Japan must diminish $\mathrm{CO}_{2}$ emission by stopping NOx elimination, and promote $\mathrm{CO}_{2}$ assimilation and fish production.

If governments think $\mathrm{CO}_{2}$ diminish is most important subject, they should consider sea as firm of fish, firm to fix $\mathrm{CO}_{2}$. They should increase N, P concentration of sea by releasing NOx and drainage $\mathrm{N}, \mathrm{P}$ as it is. 


\section{Conclusion}

Effective uses of NOx and drainage are clever way for the increase of fish production and for the protection of global warming.

\section{References}

1. Ozaki S (1993) Recycle of nitrogen and phosphorous for the increase of food production. New Food Industry35(10): 33-39.

2. Ozaki S (2016) Methods to protect global warming. Adv Tech Biol Med 4(3): 181

3. Ozaki S (2016) Methods to protect global warming, Food production increase way. New Food Industry 58(8): 47-52.

4. Ozaki S (2016) Global warming can be protected by promotion of CO2 assimilation using NOx. Journal of Climatology \& Weather Forecasting 4(2): 1000171.

5. Ozaki S (2016) Global warming can be protected by promotion of plankton $\mathrm{CO} 2$ assimilation. Journal of Marine Science: Research \& Development 6: 213.

6. Ozaki S (2017) Method to protect global warming by promotion of CO2 assimilation and method to reactivate fish industry. New Food Industry 59(3): 61-70.

7. Ozaki S (2017) NOx is Best Compound to Reduce CO2. Eur J Exp Biol 7:12.

8. Ozaki S (2017) Protection of global warming and burn out of fossil fuel by promotion of $\mathrm{CO} 2$ assimilation. J.of Marine Biology \& Oceanography 6: 2 .

9. Ozaki S (2017) Promotion of CO2 assimilation supposed by NOx is best way to protect global warming and food production. Artiv of PetEnvilron Biotechnol 02.110

10. Ozaki S (2017) Promotion of CO2 assimilation supported by NOx is best way to protect global warming. J Marine Biol Aquacult 3(2): 1-5.

11. Ozaki S (2017) Stopping of NOx elimination is easy way to reduce CO2 and protect global warming. J Environ Sci Public Health 1(1): 24-34.

12. Falkowski, Paul G (1994) The role of phytoplankton photosynthesis in global biogeochemical cycles". Photosyntheis Research 39(3): 235258.

13. Falkowski PG, Ziemann D, Kolber Z, Bienfang PK (1991) Nutrient pumping and phytoplankton response in a subtropical mesoscale eddy. Nature 352: 52-58.

14. Falkowski PG, Wilson C (1992) Phytoplankton productivity in the North Pacific ocean since 1900 and implications for absorption of anthropogenic CO2. Nature 358: 741-743.

15. Falkowski PG, Woodhead AD (1992) Primary Productivity and Biogeochemical Cycles in the Sea. Plenum Press, New York, USA, p. 550.

16. Chisholm SW, Falkowski PG, Cullen JJ (2001) Dis-crediting ocean fertilization. Science 294(5541): 309-310.

17. Aumont O, Bopp L (2006) Globalizing results from ocean in situ iron fertilization studies". Global Biogeochemical Cycles 20(2).

18. (2015) How much do oceans add to worlds oxygen? Earth \& Sky.

19. Roach J (2004) Source of Half Earth's Oxygen Gets Little Credit. National Geographic News.
20. Tappan H (1968) Primary production, isotopes, extinctions and the atmosphere. Palaeogeography, Palaeoclimatology, Palaeoecology 4(3): 187-210.

21. Wang G, Wang X, Liu X, Li Q (2012) Diversity and biogeochemical function of planktonic fungi in the ocean. In: Raghukumar C (Edt.), Biology of marine fungi. Springer Berlin Heidelberg 53: 71-88.

22. Omori M, Ikeda T (1992) Methods in Marine Zooplankton Ecology. Krieger Publishing Company, Malabar, USA, p. 332.

23. NASA Satellite Detects Red Glow to Map Global Ocean Plant Health.

24. (2014) NASA Satellite Sees Ocean Plants Increase, Coasts Greening.

25. Richtel M (2007) Recruiting Plankton to Fight Global Warming. New York Times.

26. Charlson RJ, Lovelock JE, Andreae MO, Warren SG (1987) Oceanic phytoplankton, atmospheric sulphur, cloud albedo and climate. Nature 326 (6114): 655-661.

27. Quinn PK, Bates TS (2011) The case against climate regulation via oceanic phytoplankton sulphur emissions. Nature 480(7375): 51-56.

28. Calbet A (2008) The trophic roles of microzooplankton in marine systems. ICES Journal of Marine Science 65(3): 325-331.

29. Arrigo KR (2005) Marine microorganisms and global nutrient cycles. Nature 437(7057): 349-355.

30. Fanning KA (1989) Influence of atmospheric pollution on nutrient limitation in the ocean. Nature 339(6224): 460-463.

31. Sterner RW, Elser JJ (2002) Ecological Stoichiometry: The Biology of Elements from Molecules to the Biosphere. Princeton University Press, USA.

32. Klausmeier CA, Litchman E, Levin SA (2004) Phytoplankton growth and stoichiometry under multiple nutrient limitation. Limnology and Oceanography. 49(4 Part 2): 1463-1470.

33. Klausmeier CA, Litchman E, Daufresne T, Levin SA (2004) Optimal nitrogen-to-phosphorus stoichiometry of phytoplankton. Nature 429(6988): 171-174.

34. Boyce DG, Lewis MR, Worm B (2010) Global phytoplankton decline over the past century. Nature 466(7306): 591-596.

35. Schiermeier Q (2010) Ocean greenery under warming stress. Nature.

36. Mackas DL (2011) Does blending of chlorophyll data bias temporal trend? Nature 472(7342): E4-E5.

37. Rykaczewski RR, Dunne JP (2011) A measured look at ocean chlorophyll trends. Nature. 472(7342): E5-E6.

38. McQuatters-GA, Reid PC, Edwards M, Burkill PH, Castellani C, et al. (2011) Is there a decline in marine phytoplankton? Nature 472(7342): E6-E7.

39. Boersma KF, Eskes HJ, Meijer EW, Kelder HM (2005) Estimates of lightning NOx production from GOME satellite observations. Atmos Chem Phys 5: 2311-2331.

40. Lesley EO, Kenneth E, Pickering GL, Stenchikov DJ, Allen AJ, et al. (2010) Production of lightning NOx and its vertical distribution calculated from three-dimensional cloud-scale chemical transport model simulations. Journal of Geophysical Research. 115(D4): 301.

41. Schumann U, Huntrieser H (2007) The global lightning-induced nitrogen oxides source. Atmos Chem Phys 7: 3823-3907. 

(C) (i) This work is licensed under Creative

DOI: 10.19080/OFOAJ.2017.04.555643

\section{Your next submission with Juniper Publishers} will reach you the below assets

- Quality Editorial service

- Swift Peer Review

- Reprints availability

- E-prints Service

- Manuscript Podcast for convenient understanding

- Global attainment for your research

- Manuscript accessibility in different formats ( Pdf, E-pub, Full Text, Audio)

- Unceasing customer service

Track the below URL for one-step submission https://juniperpublishers.com/online-submission.php 